\title{
DEVELOPMENT OF NEW 2-METHYL-4-SALICYLAMIDE THIAZOLE DERIVATIVES: SYNTHESIS, ANTIMICROBIAL ACTIVITY EVALUATION, LIPOPHILICITY AND MOLECULAR DOCKING STUDY
}

\author{
BIANCA POP ${ }^{1}$, IOANA IONUȚ $^{1}$, GABRIEL MARC $^{1 *}$, DAN CRISTIAN VODNAR ${ }^{2}$, ADRIAN \\ PÎRNĂU ${ }^{3}$, LAURIAN VLASE $^{1}$, OVIDIU ONIGA ${ }^{1}$ \\ I "Iuliu Hațieganu” University of Medicine and Pharmacy, Faculty of Pharmacy, 12 Ion Creangă Street, 400010, Cluj- \\ Napoca, Romania \\ ${ }^{2}$ University of Agricultural Sciences and Veterinary Medicine, Department of Food Science and Technology, 3-5 Mănăştur \\ Street, 400372, Cluj-Napoca, Romania \\ ${ }^{3}$ National Institute for Research and Development of Isotopic and Molecular Technologies, 67-103 Donath Street, 400293, \\ Cluj-Napoca, Romania
}

*corresponding author: marc.gabriel@umfcluj.ro

Manuscript received: March 2021

\begin{abstract}
A series of 15 new thiazolyl-salicylamide ethers were obtained through an alkylation reaction in alkaline medium. The compounds were physico-chemically and spectrally characterized. The evaluation of their antimicrobial activity highlighted the antifungal effect of compound $\mathbf{5 n}$, which was equivalent to that of fluconazole. A molecular docking study revealed the structurally important elements for a better interaction with target lanosterol $14 \alpha$-fungal demethylase. Given the importance of the lipophilicity for the penetration of biological membranes of bioactive molecules, this was evaluated in silico.

\section{Rezumat}

O serie de 15 noi eteri tiazolil-salicilamidici au fost obținuți prin alchilare în mediu bazic. Compușii au fost caracterizați fizico-chimic și spectral. Evaluarea activității antimicrobiene a evidențiat efectul antifungic al compusului 5 n, echivalent cu al fluconazolului. Un studiu de andocare moleculară a evidențiat elementele structurale importante pentru o bună interacțiune cu lanosterol $14 \alpha$-demetilaza fungică. Datorită importanței pe care o are lipofilia asupra penetrabilităţii prin membrane a moleculelor bioactive, aceasta a fost evaluată in silico.
\end{abstract}

Keywords: antifungal, thiazole, salicylamide, molecular docking, fluconazole

\section{Introduction}

Microbial infections represent a global crisis due to the extension of microbial resistance that leads to a progressive reduction of therapy efficacy. The improper use of antibiotics has led to the selection of microbial strains with high degrees of resistance [2,9]. The incidence of infections with multidrug resistant microorganisms is constantly increasing, being the cause of many deaths within the hospital environment. Consequently, the need for discovering new active molecules against resistant bacteria or fungi is a priority of many researchers in the field of medicinal chemistry $[5,12,17]$. Research into new molecules with potential antimicrobial activity is intense, addressing various research pathways to combat resistance [3, 4]. The present paper is a continuation of our group's research in developing new thiazole derivatives as antimicrobial agents, with various structural features. In our previous report, a series of 5-(2-(phenylamino)thiazol-4-yl)benzamide ethers were synthesized and evaluated against some microbial strains [1]. In this paper, we report the development of a new series of thiazolyl-salicylamide derivatives, using different halide-based alkylating agents, in order to obtain the desired ethers. The phenyl-amino moiety from the position 2 of the thiazole from our previous report, was replaced with a methyl residue [1]. The present research was encouraged by the favourable results obtained by other researchers in the field of obtaining thiazole derivatives with antimicrobial activity $[7,8$, $11,14]$.

\section{Materials and Methods}

\section{Chemistry}

Reagents and solvents used, produced by Merck (Darmstadt, Germany) and Alfa Aesar (Karlsruhe, Germany), were of analytical grade purity and were purchased from local suppliers and used without any further purification. The chemical synthesis was monitored by thin layer chromatography (TLC). The purity of the compounds was evaluated using TLC and RP-HPLC. The uncorrected melting points were determined using an MPM-H1 melting point meter (Schorpp Gerätetechnik, Überlingen, Germany) in open 
glass capillary. MS analyses were performed on an Agilent 1100 series, in positive ionization with an Agilent Ion Trap SL mass spectrometer (Agilent Technologies, Santa Clara, CA, USA). IR spectra were recorded using a Jasco FT/IR 6100 spectrometer (Jasco, Cremella, Italy), after compression in anhydrous $\mathrm{KBr}$ under vacuum. ${ }^{1} \mathrm{H}$ NMR analysis were performed in DMSO- $d_{6}\left(\delta_{\mathrm{H}}=2.51 \mathrm{ppm}\right)$ as solvent, on an Avance NMR spectrometer (Bruker, Karlsruhe, Germany), using tetramethylsilane (TMS) as internal standard. Synthesis of 2-hydroxy-5-(2-methylthiazol-4-yl)benzamide (3)

In a round bottom flask, $25 \mathrm{mmol}(1.875 \mathrm{~g})$ of thioacetamide (compound 1) were dissolved in $15 \mathrm{~mL}$ of ethanol. Later, $25 \mathrm{mmol}$ (6.425 g) of $\alpha$-bromoketone (compound 2) were added, in order to obtain a thiazole ring through a Hantzsch cyclisation. The mixture was refluxed for 3 hours. The resulted precipitate was filtered under vacuum after cooling. The resulted solid was placed in a beaker and neutralized using a sodium bicarbonate solution and filtered again. The resulted precipitate was filtered and dried using vacuum. The final pure product 3 was obtained after recrystallization from ethanol. Compound $\mathbf{3}$ was previously reported in the literature [18].

2-hydroxy-5-(2-methylthiazol-4-yl)benzamide (3): white solid; $\mathrm{mp}=199^{\circ} \mathrm{C}$; yield $=61 \%$; FT IR $(\mathrm{KBr}) v_{\max }$ $\mathrm{cm}^{-1}$ : $1670(\mathrm{C}=\mathrm{O}$ amide $), 1632(\mathrm{C}=\mathrm{N}), 1373(\mathrm{O}-\mathrm{H}$ bending); MS: $m / z=236.0(\mathrm{M}+1)$; ${ }^{1} \mathrm{H}$ NMR (DMSO$\left.\mathrm{d}_{6}, 500 \mathrm{MHz}\right) \delta: 2.70\left(\mathrm{~s}, 3 \mathrm{H},-\mathrm{CH}_{3}\right), 7.03(\mathrm{~d}, 1 \mathrm{H}, \mathrm{Ar})$, 7.81 (s, 1H, Th), 8.06 (d, 1H, Ar), 8.19 (br, 1H, $-\mathrm{NH}_{2}$ ),
8.61 (s, 1H, Ar), 8.78 (br, 1H, - $\mathrm{NH}_{2}$ ), 13.62 (br, $1 \mathrm{H}$, $-\mathrm{OH})$.

General procedure for synthesis of ethers 5a-o (Figure 1)

$1 \mathrm{mmol}(0.234 \mathrm{~g})$ of intermediate compound $3,5 \mathrm{mmol}$ $(0.69 \mathrm{~g})$ of anhydrous $\mathrm{K}_{2} \mathrm{CO}_{3}$ and $1 \mathrm{mmol}$ of the corresponding 4a-o halide compound were suspended in $15 \mathrm{~mL}$ of anhydrous acetone. With the exception of compound $\mathbf{5 d}$, because compound $\mathbf{4 d}$ was iodoacetamide, for the synthesis of the other fourteen compounds, $1 \mathrm{mmol}(0.166 \mathrm{~g})$ of anhydrous KI was added in order to perform a Finkelstein in situ transhalogenation reaction. The compounds $\mathbf{4 b}, \mathbf{4 e}$ and $\mathbf{4 g}$ were aliphatic chlorine derivatives, while others were aliphatic bromine derivatives (compounds $\mathbf{4 a}, \mathbf{4 c}, \mathbf{4 f}$ and 4h-o). Supplementary, $1 \mathrm{mmol}(0.138 \mathrm{~g})$ of anhydrous $\mathrm{K}_{2} \mathrm{CO}_{3}$ was added for the synthesis of the compound $\mathbf{5 g}$, to neutralize the acidity given by the carboxyl group. The mixture was refluxed for three hours. After the disappearance of the compound $\mathbf{3}$ from the reaction flask, confirmed by TLC, the acetone was removed using a rotational evaporator under vacuum. The remaining solid was mixed with water and a $10 \%$ sulphuric acid was added until the complete precipitation of the final product. The resulted precipitate was filtered under vacuum and dried. The impure solid was crystallized from methanol, in order to give the pure desired products 5a-o. The purity of the final compounds was confirmed using TLC and RPHPLC.

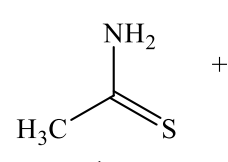

1

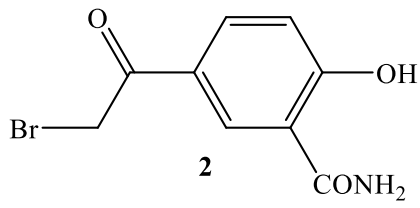

2
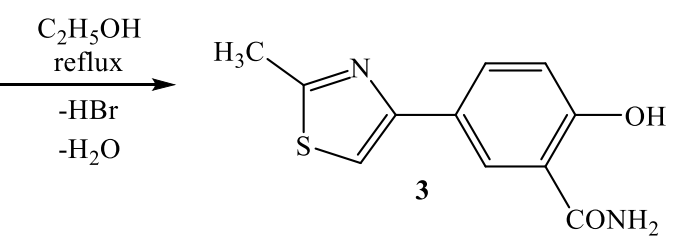

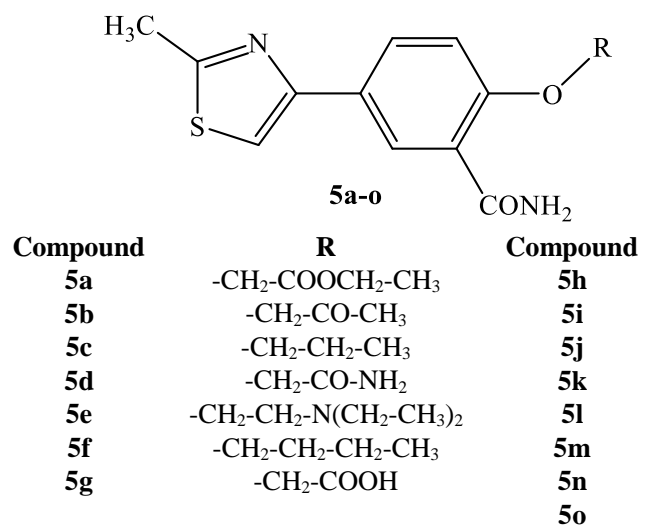

Figure 1.

The synthetic route followed in order to obtain the thiazolyl-salicylamide ethers 5a-o 
Ethyl 2-(2-carbamoyl-4-(2-methylthiazol-4-yl)phenoxy)acetate (5a): white solid; $\mathrm{mp}=152^{\circ} \mathrm{C}$; yield $=88 \%$; FT IR (KBr) $v_{\max } \mathrm{cm}^{-1}: 1744(\mathrm{C}=\mathrm{O}$ ester $), 1672$ (C=O amide), $1639(\mathrm{C}=\mathrm{N}), 1257$ (C-O-C ether asymm str), 1026 (C-O-C ether symm str); MS: $m / z=322.1$ $(\mathrm{M}+1) ;{ }^{1} \mathrm{H}$ NMR (DMSO- $\left.d_{6}, 500 \mathrm{MHz}\right) \delta: 1.29(\mathrm{t}$, $\left.3 \mathrm{H},-\mathrm{CH}_{3}\right), 2.71$ (s, 3H, $\left.-\mathrm{CH}_{3}\right), 4.24$ (q, $2 \mathrm{H},-\mathrm{CH}_{2}-$ ), $5.11\left(\mathrm{~s}, 2 \mathrm{H},-\mathrm{CH}_{2}-\right), 7.28$ (d, 1H, Ar), $7.86(\mathrm{~s}, 1 \mathrm{H}, \mathrm{Th})$, 8.09 (d, 1H, Ar), 8.58 (m, 2H, Ar, - $\mathrm{NH}_{2}$ ), 9.09 (br, $\left.1 \mathrm{H},-\mathrm{NH}_{2}\right)$.

5-(2-Methylthiazol-4-yl)-2-(2-oxopropoxy)benzamide

(5b): yellow solid; $\mathrm{mp}=188^{\circ} \mathrm{C}$; yield $=62 \%$; FT IR (KBr) $v_{\max } \mathrm{cm}^{-1}: 1731(\mathrm{C}=\mathrm{O}$ ketone $), 1671(\mathrm{C}=\mathrm{O}$ amide), $1638(\mathrm{C}=\mathrm{N}), 1278$ (C-O-C ether asymm str), 1064 (C-O-C ether symm str); MS: $m / z=291.1(\mathrm{M}+1)$; ${ }^{1} \mathrm{H}$ NMR (DMSO- $\left.d_{6}, 500 \mathrm{MHz}\right) \delta: 2.29$ (s, 3H, -CH ), $2.71\left(\mathrm{~s}, 3 \mathrm{H},-\mathrm{CH}_{3}\right), 4.99\left(\mathrm{~s}, 2 \mathrm{H},-\mathrm{CH}_{2}-\right), 7.21(\mathrm{~d}, 1 \mathrm{H}$, Ar), 7.84 (s, 1H, Th), 8.19 (d, 1H, Ar), 8.28 (m, 2H, $\left.\mathrm{Ar},-\mathrm{NH}_{2}\right), 8.55$ (s, 1H, Ar), 9.06 (br, $\left.1 \mathrm{H},-\mathrm{NH}_{2}\right)$.

5-(2-Methylthiazol-4-yl)-2-propoxybenzamide (5c): white solid; $\mathrm{mp}=206^{\circ} \mathrm{C}$; yield $=75 \%$; FT IR $(\mathrm{KBr})$ $\nu_{\max } \mathrm{cm}^{-1}: 1670(\mathrm{C}=\mathrm{O}$ amide $), 1637(\mathrm{C}=\mathrm{N}), 1256$ (C-O-C ether asymm str), 1067 (C-O-C ether symm str); MS: $m / z=277.3(\mathrm{M}+1) ;{ }^{1} \mathrm{H}$ NMR (DMSO- $d_{6}$, $500 \mathrm{MHz}) \delta: 1.01\left(\mathrm{t}, 3 \mathrm{H},-\mathrm{CH}_{3}\right), 1.69\left(\mathrm{~m}, 2 \mathrm{H},-\mathrm{CH}_{2}-\right)$, $2.75\left(\mathrm{~s}, 3 \mathrm{H},-\mathrm{CH}_{3}\right), 3.96\left(\mathrm{~s}, 2 \mathrm{H},-\mathrm{CH}_{2}-\right), 7.16(\mathrm{~d}, 1 \mathrm{H}$, Ar), 7.90 (s, 1H, Th), 8.10 (d, 1H, Ar), 8.26 (m, 2H, Ar, $\left.-\mathrm{NH}_{2}\right), 8.50$ (s, 1H, Ar), 8.99 (br, $1 \mathrm{H},-\mathrm{NH}_{2}$ ). 2-(2-Amino-2-oxoethoxy)-5-(2-methylthiazol-4-yl)benzamide (5d): white solid; $\mathrm{mp}=233-224^{\circ} \mathrm{C}$; yield $=$ 51\%; FT IR (KBr) $v_{\max } \mathrm{cm}^{-1}: 1670(\mathrm{C}=\mathrm{O}$ amide), $1636(\mathrm{C}=\mathrm{N}), 1268$ (C-O-C ether asymm str), 1048 (C-O-C ether symm str); MS: $m / z=292.1(\mathrm{M}+1)$; ${ }^{1} \mathrm{H}$ NMR (DMSO-d $\left.d_{6}, 500 \mathrm{MHz}\right) \delta: 2.73\left(\mathrm{~s}, 3 \mathrm{H},-\mathrm{CH}_{3}\right)$, 4.58 (s, 2H, $\left.-\mathrm{CH}_{2}-\right), 7.01$ (br, $\left.2 \mathrm{H},-\mathrm{NH}_{2}\right) 7.15$ (d, 1H, Ar), 7.80 (s, 1H, Th), 8.16 (d, 1H, Ar), 8.25 (m, 2H, $\left.\mathrm{Ar},-\mathrm{NH}_{2}\right), 8.50$ (s, 1H, Ar), 9.51 (br, $\left.1 \mathrm{H},-\mathrm{NH}_{2}\right)$. 2-(2-(Diethylamino)ethoxy)-5-(2-methylthiazol-4yl)benzamide (5e): pale yellow solid; $\mathrm{mp}=128^{\circ} \mathrm{C}$; yield $=29 \%$; FT IR $(\mathrm{KBr}) v_{\max } \mathrm{cm}^{-1}: 1674(\mathrm{C}=\mathrm{O}$ amide), $1637(\mathrm{C}=\mathrm{N}), 1273$ (C-O-C ether asymm str), 1053 (C-O-C ether symm str); MS: $m / z=334.5$ $(\mathrm{M}+1) ;{ }^{1} \mathrm{H}$ NMR (DMSO- $\left.d_{6}, 500 \mathrm{MHz}\right) \delta: 1.05(\mathrm{t}$, $\left.6 \mathrm{H},-\mathrm{CH}_{3}\right), 2.59\left(\mathrm{t}, 2 \mathrm{H},-\mathrm{CH}_{2}-\right), 2.65\left(\mathrm{~m}, 4 \mathrm{H},-\mathrm{CH}_{2-}\right)$, $2.71\left(\mathrm{~s}, 3 \mathrm{H},-\mathrm{CH}_{3}\right), 3.99\left(\mathrm{~d}, 2 \mathrm{H},-\mathrm{CH}_{2}-\right), 7.22(\mathrm{~d}, 1 \mathrm{H}$, Ar), 7.88 (s, 1H, Th), 8.18 (m, 2H, Ar, $\left.-\mathrm{NH}_{2}\right), 8.50$ (s, 1H, Ar), 8.99 (br, 1H, - $\mathrm{NH}_{2}$ ).

2-Butoxy-5-(2-methylthiazol-4-yl)benzamide (5f): white solid; $\mathrm{mp}=139^{\circ} \mathrm{C}$; yield $=63 \%$; FT IR $(\mathrm{KBr})$ $v_{\max } \mathrm{cm}^{-1}: 1672(\mathrm{C}=\mathrm{O}$ amide $), 1637(\mathrm{C}=\mathrm{N}), 1245$ (C-O-C ether asymm str), 1035 (C-O-C ether symm str); MS: $m / z=291.2(\mathrm{M}+1) ;{ }^{1} \mathrm{H}$ NMR (DMSO- $d_{6}$, $500 \mathrm{MHz}) \delta: 1.01\left(\mathrm{t}, 3 \mathrm{H},-\mathrm{CH}_{3}\right), 1.40\left(\mathrm{~m}, 2 \mathrm{H},-\mathrm{CH}_{2}-\right)$, $1.69\left(\mathrm{~m}, 2 \mathrm{H},-\mathrm{CH}_{2}-\right), 2.70\left(\mathrm{~s}, 3 \mathrm{H},-\mathrm{CH}_{3}\right), 3.91(\mathrm{~d}, 2 \mathrm{H}$, $-\mathrm{CH}_{2}$ ), 7.19 (d, 1H, Ar), 7.81 (s, 1H, Th), 8.13 (d, 1H,
Ar), 8.54 (s, 1H, Ar), 8.65 (br, 1H, - $\mathrm{NH}_{2}$ ), 9.28 (br, $\left.1 \mathrm{H},-\mathrm{NH}_{2}\right)$.

2-(2-Carbamoyl-4-(2-methylthiazol-4-yl)phenoxy)acetic acid $(\mathbf{5 g})$ : white solid; $\mathrm{mp}=162^{\circ} \mathrm{C}$; yield $=$ 41\%; FT IR (KBr) $v_{\max } \mathrm{cm}^{-1}: 1711$ (C=O acid), 1671 $(\mathrm{C}=\mathrm{O}$ amide), $1637(\mathrm{C}=\mathrm{N}), 1257$ (C-O-C ether asymm str), 1026 (C-O-C ether symm str); MS: $m / z=293.1$ $(\mathrm{M}+1) ;{ }^{1} \mathrm{H}$ NMR (DMSO- $\left.d_{6}, 500 \mathrm{MHz}\right) \delta: 2.74$ (s, $\left.3 \mathrm{H},-\mathrm{CH}_{3}\right), 4.81$ (d, 2H, $\left.-\mathrm{CH}_{2}-\right), 7.29$ (d, 1H, Ar), 7.88 (s, 1H, Th), 8.18 (d, 1H, Ar), 8.52 (s, 1H, Ar), 8.17 (br, $\left.1 \mathrm{H},-\mathrm{NH}_{2}\right), 8.85$ (br, $\left.1 \mathrm{H},-\mathrm{NH}_{2}\right)$.

5-(2-Methylthiazol-4-yl)-2-(2-(4-nitrophenyl)-2-

oxoethoxy)benzamide $(\mathbf{5 h})$ : brown solid; $\mathrm{mp}=199^{\circ} \mathrm{C}$; yield $=59 \%$; FT IR $(\mathrm{KBr}) v_{\max } \mathrm{cm}^{-1}: 1670(\mathrm{C}=\mathrm{O}$ amide), $1637(\mathrm{C}=\mathrm{N}), 1524(\mathrm{~N}=\mathrm{O}$ nitro asymm str), 1349 ( $\mathrm{N}=\mathrm{O}$ nitro symm str), 1258 (C-O-C ether asymm str), 1062 (C-O-C ether symm str); MS: $m / z=398.3$ $(\mathrm{M}+1) ;{ }^{1} \mathrm{H}$ NMR (DMSO- $\left.d_{6}, 500 \mathrm{MHz}\right) \delta: 2.73$ (s, $\left.3 \mathrm{H},-\mathrm{CH}_{3}\right), 5.20\left(\mathrm{~s}, 2 \mathrm{H},-\mathrm{CH}_{2}-\right), 7.18(\mathrm{~d}, 1 \mathrm{H}, \mathrm{Ar})$, 7.84 (s, 1H, Th), 8.17 (d, 1H, Ar), 8.29 (m, 3H, Ar, $\left.-\mathrm{NH}_{2}\right), 8.36$ (d, 2H, Ar), 8.55 (s, 1H, Ar), 9.06 (br, $\left.1 \mathrm{H},-\mathrm{NH}_{2}\right)$.

5-(2-Methylthiazol-4-yl)-2-(2-oxo-2-phenylethoxy)benzamide $(\mathbf{5 i})$ : white solid; $\mathrm{mp}=204^{\circ} \mathrm{C}$; yield $=$ 83\%; FT IR (KBr) $v_{\max } \mathrm{cm}^{-1}: 1673$ (C=O amide), $1637(\mathrm{C}=\mathrm{N}), 1238$ (C-O-C ether asymm str), 1074 (C-O-C ether symm str); MS: $m / z=353.2(\mathrm{M}+1)$; ${ }^{1} \mathrm{H}$ NMR (DMSO- $\left.d_{6}, 500 \mathrm{MHz}\right) \delta: 2.73\left(\mathrm{~s}, 3 \mathrm{H},-\mathrm{CH}_{3}\right)$, $5.24\left(\mathrm{~s}, 2 \mathrm{H},-\mathrm{CH}_{2}-\right), 7.37$ (d, 1H, Ar), $7.62(\mathrm{~d}, 2 \mathrm{H}$, $\mathrm{Ar}), 7.74$ (t, 1H, Ar), 7.79 (br, 1H, $\left.-\mathrm{NH}_{2}\right), 7.89$ (s, $1 \mathrm{H}, \mathrm{Th}), 8.05$ (d, 1H, Ar), 8.11 (d, 2H, Ar), 8.46 (br, $\left.1 \mathrm{H},-\mathrm{NH}_{2}\right), 8.58(\mathrm{~s}, 1 \mathrm{H}, \mathrm{Ar})$.

2-(2-(4-Chlorophenyl)-2-oxoethoxy)-5-(2-methylthiazol-4-yl)benzamide (5j): white solid; $\mathrm{mp}=232^{\circ} \mathrm{C}$; yield $=42 \%$; FT IR $(\mathrm{KBr}) v_{\max } \mathrm{cm}^{-1}: 1691(\mathrm{C}=\mathrm{O}$ ketone), $1670(\mathrm{C}=\mathrm{O}$ amide $), 1638(\mathrm{C}=\mathrm{N}), 1230(\mathrm{C}-\mathrm{O}-\mathrm{C}$ ether asymm str), 1052 (C-O-C ether symm str); MS: $m / z=387.6(\mathrm{M}+1$, with specific aspect due to chlorine isotopes ${ }^{35} \mathrm{Cl}$ and ${ }^{37} \mathrm{Cl}$ in approximately 3:1 ratio); ${ }^{1} \mathrm{H}$ NMR (DMSO- $\left.d_{6}, 500 \mathrm{MHz}\right) \delta: 2.70\left(\mathrm{~s}, 3 \mathrm{H},-\mathrm{CH}_{3}\right)$, 5.17 (s, 2H, - $\left.\mathrm{CH}_{2}-\right), 7.25$ (d, 1H, Ar), 7.54 (d, 2H, Ar), 7.85 (s, 1H, Th), 8.06 (m, 3H, Ar), 8.59 (s, 1H, Ar), 8.90 (br, $\left.1 \mathrm{H},-\mathrm{NH}_{2}\right), 9.21$ (br, $\left.1 \mathrm{H},-\mathrm{NH}_{2}\right)$.

5-(2-Methylthiazol-4-yl)-2-(2-(naphthalen-2-yl)-2oxoethoxy)benzamide (5k): yellow solid; $\mathrm{mp}=196^{\circ} \mathrm{C}$; yield $=40 \%$; FT IR $(\mathrm{KBr}) v_{\max } \mathrm{cm}^{-1}: 1697(\mathrm{C}=\mathrm{O}$ ketone), 1672 ( $\mathrm{C}=\mathrm{O}$ amide), $1638(\mathrm{C}=\mathrm{N}), 1273(\mathrm{C}-\mathrm{O}-\mathrm{C}$ ether asymm str), 1069 (C-O-C ether symm str); MS: $m / z=403.2(\mathrm{M}+1) ;{ }^{1} \mathrm{H}$ NMR (DMSO- $\left.d_{6}, 500 \mathrm{MHz}\right)$ $\delta: 2.70\left(\mathrm{~s}, 3 \mathrm{H},-\mathrm{CH}_{3}\right), 5.18\left(\mathrm{~s}, 2 \mathrm{H},-\mathrm{CH}_{2}-\right), 7.29(\mathrm{~d}$, $1 \mathrm{H}, \mathrm{Ar}), 7.65$ (m, 2H, Ar), $7.82(\mathrm{~m}, 2 \mathrm{H}, \mathrm{Ar}, \mathrm{Th})$, 7.92 (d, 1H, Ar), 8.06 (m, 3H, Ar), 8.30 (m, 2H, Ar, $\left.-\mathrm{NH}_{2}\right), 8.59$ (s, $\left.1 \mathrm{H}, \mathrm{Ar}\right), 8.89$ (br, $\left.1 \mathrm{H},-\mathrm{NH}_{2}\right)$. 2-(2-(4-Methoxyphenyl)-2-oxoethoxy)-5-(2-methylthiazol-4-yl)benzamide (5l): yellow solid; $\mathrm{mp}=199^{\circ} \mathrm{C}$; yield $=52 \%$; FT IR $(\mathrm{KBr}) v_{\max } \mathrm{cm}^{-1}: 1695(\mathrm{C}=\mathrm{O}$ 
FARMACIA, 2021, Vol. 69, 4

ketone), $1671(\mathrm{C}=\mathrm{O}$ amide $), 1638(\mathrm{C}=\mathrm{N}), 1260$ (C-O-C ether asymm str), 1058 (C-O-C ether symm str); MS: $m / z=383.3(\mathrm{M}+1) ;{ }^{1} \mathrm{H}$ NMR (DMSO- $d_{6}$, $500 \mathrm{MHz}) \delta: 2.74\left(\mathrm{~s}, 3 \mathrm{H},-\mathrm{CH}_{3}\right), 3.88\left(\mathrm{~s}, 3 \mathrm{H},-\mathrm{OCH}_{3}\right)$, $5.15\left(\mathrm{~s}, 2 \mathrm{H},-\mathrm{CH}_{2}-\right), 7.12(\mathrm{~d}, 1 \mathrm{H}, \mathrm{Ar}), 7.28(\mathrm{~d}, 2 \mathrm{H}, \mathrm{Ar})$, 7.83 (s, 1H, Th), 8.01 (d, 2H, Ar), 8.15 (d, 1H, Ar), 8.24 (br, $\left.1 \mathrm{H},-\mathrm{NH}_{2}\right), 8.50$ (s, 1H, Ar), 9.51 (br, $1 \mathrm{H}$, $-\mathrm{NH}_{2}$ ).

5-(2-Methylthiazol-4-yl)-2-((1-oxo-1-phenylpropan2-yl)oxy)benzamide $(\mathbf{5 m})$ : pale yellow solid; $\mathrm{mp}=$ $193^{\circ} \mathrm{C}$; yield $=44 \%$; FT IR $(\mathrm{KBr}) v_{\max } \mathrm{cm}^{-1}: 1696$ $(\mathrm{C}=\mathrm{O}$ ketone $), 1672(\mathrm{C}=\mathrm{O}$ amide $), 1637(\mathrm{C}=\mathrm{N}), 1256$ (C-O-C ether asymm str), 1056 (C-O-C ether symm str); MS: $m / z=367.3(\mathrm{M}+1) ;{ }^{1} \mathrm{H}$ NMR (DMSO- $d_{6}$, $500 \mathrm{MHz}) \delta: 1.49\left(\mathrm{~s}, 3 \mathrm{H},-\mathrm{CH}_{3}\right), 2.71\left(\mathrm{~s}, 3 \mathrm{H},-\mathrm{CH}_{3}\right)$, $5.28(\mathrm{~m}, 1 \mathrm{H}, \mathrm{CH}), 7.21(\mathrm{~d}, 1 \mathrm{H}, \mathrm{Ar}), 7.63(\mathrm{t}, 2 \mathrm{H}, \mathrm{Ar})$, 7.73 (s, 1H, Ar), 7.82 (s, 1H, Th), 8.11 (m, 3H, Ar), $8.50(\mathrm{~s}, 1 \mathrm{H}, \mathrm{Ar}), 8.64\left(\mathrm{br}, 1 \mathrm{H},-\mathrm{NH}_{2}\right), 9.03(\mathrm{br}, 1 \mathrm{H}$, $\left.-\mathrm{NH}_{2}\right)$.

2-(2-(4-Bromophenyl)-2-oxoethoxy)-5-(2-methylthiazol-4-yl)benzamide (5n): pale yellow solid; $\mathrm{mp}=$ $237^{\circ} \mathrm{C}$; yield $=51 \%$; FT IR $(\mathrm{KBr}) v_{\max } \mathrm{cm}^{-1}: 1693$ $(\mathrm{C}=\mathrm{O}$ ketone), $1671(\mathrm{C}=\mathrm{O}$ amide $), 1638(\mathrm{C}=\mathrm{N}), 1275$ (C-O-C ether asymm str), 1068 (C-O-C ether symm str); MS: $m / z=431.1(\mathrm{M}+1$, with specific aspect due to bromine isotopes ${ }^{79} \mathrm{Br}$ and ${ }^{81} \mathrm{Br}$ in approximately 1:1 ratio); ${ }^{1} \mathrm{H}$ NMR (DMSO- $\left.d_{6}, 500 \mathrm{MHz}\right) \delta: 2.70$ $\left(\mathrm{s}, 3 \mathrm{H},-\mathrm{CH}_{3}\right), 5.16(\mathrm{~s}, 1 \mathrm{H}, \mathrm{CH}), 7.17(\mathrm{~d}, 1 \mathrm{H}, \mathrm{Ar})$, 7.60 (d, 2H, Ar), 7.82 (s, 1H, Th), 7.98 (d, 2H, Ar), 8.09 (d, 1H, Ar), $8.22\left(\mathrm{br}, 1 \mathrm{H},-\mathrm{NH}_{2}\right), 8.52(\mathrm{~s}, 1 \mathrm{H}$, Ar), 9.02 (br, $1 \mathrm{H},-\mathrm{NH}_{2}$ ).

2-(2-(4-Cyanophenyl)-2-oxoethoxy)-5-(2-methylthiazol4-yl)benzamide (5o): yellow solid; $\mathrm{mp}=193^{\circ} \mathrm{C}$; yield $=25 \%$; FT IR $(\mathrm{KBr}) v_{\max } \mathrm{cm}^{-1}: 2229(\mathrm{C} \equiv \mathrm{N})$, $1706(\mathrm{C}=\mathrm{O}$ ketone), $1671(\mathrm{C}=\mathrm{O}$ amide $), 1638(\mathrm{C}=\mathrm{N})$, 1278 (C-O-C ether asymm str), 1072 (C-O-C ether symm str); MS: $m / z=378.2(\mathrm{M}+1) ;{ }^{1} \mathrm{H}$ NMR (DMSO- $\left.d_{6}, 500 \mathrm{MHz}\right) \delta: 2.74\left(\mathrm{~s}, 3 \mathrm{H},-\mathrm{CH}_{3}\right), 5.12$ (s, 1H, CH), 7.19 (d, 1H, Ar), 7.79 (d, 2H, Ar), 7.81 (s, $1 \mathrm{H}, \mathrm{Th}), 8.15$ (d, 2H, Ar), 8.19 (d, 1H, Ar), 8.23 (br, $\left.1 \mathrm{H},-\mathrm{NH}_{2}\right), 8.52$ (s, $\left.1 \mathrm{H}, \mathrm{Ar}\right), 8.98\left(\mathrm{br}, 1 \mathrm{H},-\mathrm{NH}_{2}\right.$ ).

Antimicrobial activity

The antimicrobial evaluation was performed as previously reported, based on the serial double microdilution technique on 96 well microplates [10]. By dissolving the test compounds, the reference antifungal agent (fluconazole) and the reference antibacterial agent (streptomycin) in sterile DMSO, stock solutions (1 $\mathrm{mg} / \mathrm{mL}$ ) were prepared. The resulted solutions were stored in a refrigerator at $4^{\circ} \mathrm{C}$ until using. The solvent used (DMSO) showed no inhibition of the fungal growth and was used as negative control. The microorganisms used for this assay were obtained from the Food Biotechnology Laboratory, Life Sciences Institute, University of Agricultural Sciences and Veterinary Medicine Cluj-Napoca, Romania and cultured on Muller-Hinton broth. The MIC and MMC values were determined against cultures of $S$. aureus ATCC 49444, E. coli ATCC 25922, P. aeruginosa ATCC 27853, S. typhimurium ATCC 14028, $C$. albicans ATCC 10231, C. parapsilosis ATCC 22019 and $C$. zeylanoides ATCC 201082. The cell suspensions were adjusted with sterile saline to a concentration of approximately $3 \times 10^{5} \mathrm{CFU} / \mathrm{mL}$ in a final volume of $100 \mu \mathrm{L}$ per well. The samples were carried out over the wells containing $100 \mu \mathrm{L}$ MHB and afterward, $10 \mu \mathrm{L}$ of inoculum was added to all the wells. The microplates were incubated for $18 \mathrm{~h}$ at $37^{\circ} \mathrm{C}$. The microbicidal activity of the samples was detected following the addition of $20 \mu \mathrm{L}$ of resazurin solution $(0.2 \mathrm{mg} / \mathrm{mL})$ to each well, and the plates were incubated $2 \mathrm{~h}$ at $37^{\circ} \mathrm{C}$. A change from blue to pink indicates a reduction of resazurin and therefore microbial growth. The results of the antimicrobial activity were expressed as the minimum inhibitory concentration (MIC) and the minimum microbicidal concentration (MMC), depending on the changing of the colour of the solution from wells.

Molecular docking study

A molecular docking study was performed using AutoDock 4.2 [13], using as target the fungal lanosterol $14 \alpha$-demethylase built by homology modelling, as previously reported [10]. The preparation protocol of the ligands and of the target macromolecule performed as previously reported, using AutoDockTools 1.5.6 [13]. In order to have a better understanding of the interactions of the ligands with the target macromolecule, the number of searched conformations was increased to 200, compared to the previously reported experiments. The other parameters were left unchanged, as previously reported [10]. Depiction of the interactions between the target and the ligand was made using UCSF Chimera 1.10.2 [15].

Lipophilicity evaluation

Given the importance of lipophilicity for the penetration of microbial membranes by bioactive compounds [16], the theoretical $\log \mathrm{P}$ of the newly synthesized thiazolylsalicylamide derivatives 5a-o was computationally estimated using Swiss-ADME [6].

\section{Results and Discussion}

\section{Chemistry}

As we hoped, spectral data confirmed the structures of the obtained compounds 5a-o. Compound $\mathbf{3}$ spectral signals confirmed its obtaining. In the IR spectrum, the appearance of a strong signal at $1670 \mathrm{~cm}^{-1}$ given by the stretching of the amide $\mathrm{C}=\mathrm{O}$ bond and the presence of another signal given by the bending of phenolic $\mathrm{O}-\mathrm{H}$ confirmed the presence of the salicylamide fragment in the newly obtained compound. In addition, the stretching of the $\mathrm{C}=\mathrm{N}$ bond, a new type of bond, compared to the starting compound $\mathbf{1}$, confirmed the successful formation of the thiazole nucleus through the Hantzsch reaction. The molecular peak of the 
compound was found in its mass spectra, confirming one more time the obtaining of the desired intermediate compound 3. ${ }^{1} \mathrm{H}$ NMR spectra was consistent with the expected data, in terms of number of protons, their deshielding and multiplicity. For example, at 7.81 ppm a strong sharp singlet signal of the $\mathrm{C}_{5}-\mathrm{H}$ proton confirms the formation of the thiazole ring, while the appearance of three broad signals, corresponding of one exchangeable proton each, confirms again the successful obtaining of the intermediate compound $\mathbf{3}$. Two of the signals are given by the amide protons and one from the phenol proton.

The obtaining of the final compounds 5a-o was confirmed by the appearance in their IR spectra of two characteristic signals, given by the stretching of the newly resulted etheric bond: asymmetric, between $1230-1278 \mathrm{~cm}^{-1}$, and a symmetric stretching between $1026-1074 \mathrm{~cm}^{-1}$, respectively. The presence of the amidic $\mathrm{C}=\mathrm{O}$ bond stretching at almost identical wavenumbers as for the starting compound, proved that the amide fragment was not subjected to chemical reaction and the chemical modulation took place only at the phenol moiety. Other signals given by ester (compound 5a), ketone (compound 5b), acid (compound 5g), nitro (compound 5h) or nitrile (compound 5o) could be easily identified in the IR spectrum, proving that the insertion of those fragments was successful. The mass spectra were concordance with the expected data for the final compounds, presenting even the characteristic pattern given by halide atoms (compounds 5j and 5n) for the specified compounds. The ${ }^{1} \mathrm{H}$ NMR data of compounds 5a-o were consistent with the expected data, in terms of number of protons, their deshielding and multiplicity. From the three broad signals given by the salicylamide fragment, the phenol signal disappeared, remaining only the two broad signals given by the exchangeable protons of the amide moiety. Antimicrobial activity

The results of the antimicrobial screening of compounds 5a-o are presented in Table I as minimum inhibitory concentration (MIC) and in Table II as minimum microbicidal concentration (MMC), against the microbial strains taken into the antimicrobial assay. With the exception of compound $\mathbf{5 n}$, most compounds exhibited low antibacterial and antifungal activities, with MIC and MMC values higher than those of the reference drugs, fluconazole and streptomycin, respectively. Compound $\mathbf{5 n}$ exhibited a much stronger antifungal activity compared to the other newly synthesized compounds from the present series. Against $C$. albicans ATCC 10231 and C. zeylanoides ATCC 201082 strains, derivative $\mathbf{5 n}$ was equally active as the reference compound fluconazole, with a $15.62 \mu \mathrm{g} / \mathrm{mL}$ MIC value, and a $31.24 \mu \mathrm{g} / \mathrm{mL}$ MMC value, respectively. Against C. parapsilosis ATCC 22019 strain, compound 5n was slightly less active than fluconazole, with a MIC value equal to $15.62 \mu \mathrm{g} / \mathrm{mL}$ versus $7.81 \mu \mathrm{g} / \mathrm{mL}$ for fluconazole. The fungicide activity expressed as MMC values against all the three fungal strains were of $31.24 \mu \mathrm{g} / \mathrm{mL}$, identical with those obtained for the reference drug against C. albicans ATCC 10231 and C. zeylanoides ATCC 201082 strains and double against C. parapsilosis ATCC 22019 strain.

Table I

Minimum inhibitory concentration $(\mu \mathrm{g} / \mathrm{mL})$ values for compounds $\mathbf{5 a - 0}$

\begin{tabular}{|c|c|c|c|c|c|c|c|}
\hline Compound & $\begin{array}{c}\text { S. aureus } \\
\text { ATCC 49444 }\end{array}$ & $\begin{array}{c}\boldsymbol{E} \text {. coli } \\
\text { ATCC 25922 }\end{array}$ & $\begin{array}{c}\text { P. aeruginosa } \\
\text { ATCC 27853 }\end{array}$ & $\begin{array}{c}\text { S. typhimurium } \\
\text { ATCC 14028 }\end{array}$ & $\begin{array}{c}\text { C. albicans } \\
\text { ATCC 10231 }\end{array}$ & $\begin{array}{c}\text { C. parapsilosis } \\
\text { ATCC 22019 }\end{array}$ & $\begin{array}{c}\text { C. zeylanoides } \\
\text { ATCC 201082 }\end{array}$ \\
\hline $\mathbf{5 a}$ & 125 & 125 & 125 & 125 & 62.5 & 62.5 & 125 \\
\hline $\mathbf{5 b}$ & 125 & 125 & 125 & 125 & 62.5 & 62.5 & 125 \\
\hline $\mathbf{5 c}$ & 125 & 125 & 125 & 125 & 62.5 & 62.5 & 125 \\
\hline $\mathbf{5 d}$ & 125 & 125 & 125 & 125 & 62.5 & 62.5 & 125 \\
\hline $\mathbf{5 e}$ & 62.5 & 62.5 & 125 & 125 & 62.5 & 62.5 & 125 \\
\hline $\mathbf{5 f}$ & 125 & 125 & 125 & 125 & 62.5 & 62.5 & 125 \\
\hline $\mathbf{5 g}$ & 62.5 & 62.5 & 125 & 125 & 62.5 & 62.5 & 125 \\
\hline $\mathbf{5 h}$ & 125 & 125 & 125 & 125 & 62.5 & 62.5 & 125 \\
\hline $\mathbf{5 i}$ & 125 & 125 & 125 & 125 & 62.5 & 62.5 & 62.5 \\
\hline $\mathbf{5 j}$ & 125 & 125 & 125 & 125 & 62.5 & 62.5 & 62.5 \\
\hline $\mathbf{5 k}$ & 125 & 62.5 & 125 & 125 & 62.5 & 62.5 & 125 \\
\hline $\mathbf{5 l}$ & 62.5 & 62.5 & 125 & 125 & 62.5 & 62.5 & 125 \\
\hline $\mathbf{5 m}$ & 62.5 & 62.5 & 125 & 125 & 62.5 & 62.5 & 62.5 \\
\hline $\mathbf{5 n}$ & 125 & 125 & 125 & 125 & $\mathbf{1 5 . 6 2}$ & $\mathbf{1 5 . 6 2}$ & $\mathbf{1 5 . 6 2}$ \\
\hline $\mathbf{5 0}$ & 62.5 & 62.5 & 125 & 125 & 62.5 & 62.5 & 125 \\
\hline Fluconazole & NT & NT & NT & NT & 15.62 & 7.81 & 15.62 \\
\hline Streptomycin & 0.03 & 0.12 & 0.06 & 0.06 & NT & NT & NT \\
\hline
\end{tabular}

NT $=$ not tested 
Minimum microbicidal concentration $(\mu \mathrm{g} / \mathrm{mL})$ of compounds 5a-o

\begin{tabular}{|c|c|c|c|c|c|c|c|}
\hline Compound & $\begin{array}{c}\text { S. aureus } \\
\text { ATCC 49444 }\end{array}$ & $\begin{array}{c}\boldsymbol{E} \text {. coli } \\
\text { ATCC 25922 }\end{array}$ & $\begin{array}{c}\text { P. aeruginosa } \\
\text { ATCC 27853 }\end{array}$ & $\begin{array}{c}\text { S. typhimurium } \\
\text { ATCC 14028 }\end{array}$ & $\begin{array}{c}\text { C. albicans } \\
\text { ATCC 10231 }\end{array}$ & $\begin{array}{c}\text { C. parapsilosis } \\
\text { ATCC 22019 }\end{array}$ & $\begin{array}{c}\text { C. zylanoides } \\
\text { ATCC 201082 }\end{array}$ \\
\hline $\mathbf{5 a}$ & 250 & 250 & 250 & 250 & 125 & 125 & 250 \\
\hline $\mathbf{5 b}$ & 250 & 250 & 250 & 250 & 125 & 125 & 250 \\
\hline $\mathbf{5 c}$ & 250 & 250 & 250 & 250 & 125 & 125 & 250 \\
\hline $\mathbf{5 d}$ & 250 & 250 & 250 & 250 & 125 & 125 & 125 \\
\hline $\mathbf{5 e}$ & 125 & 125 & 250 & 250 & 125 & 125 & 250 \\
\hline $\mathbf{5 f}$ & 250 & 250 & 250 & 250 & 125 & 125 & 250 \\
\hline $\mathbf{5 g}$ & 125 & 125 & 250 & 250 & 125 & 125 & 250 \\
\hline $\mathbf{5 h}$ & 250 & 250 & 250 & 250 & 125 & 125 & 250 \\
\hline $\mathbf{5 i}$ & 250 & 250 & 250 & 250 & 125 & 125 & 250 \\
\hline $\mathbf{5 j}$ & 250 & 250 & 250 & 250 & 125 & 125 & 250 \\
\hline $\mathbf{5 k}$ & 250 & 125 & 250 & 250 & 125 & 125 & 250 \\
\hline $\mathbf{5 l}$ & 125 & 125 & 250 & 250 & 125 & 125 & 250 \\
\hline $\mathbf{5 m}$ & 125 & 125 & 250 & 250 & 125 & 125 & 125 \\
\hline $\mathbf{5 n}$ & 250 & 250 & 250 & 250 & $\mathbf{3 1 . 2 4}$ & $\mathbf{3 1 . 2 4}$ & $\mathbf{3 1 . 2 4}$ \\
\hline $\mathbf{5 0}$ & 125 & 125 & 250 & 250 & 125 & 125 & 250 \\
\hline Fluconazole & NT & NT & NT & NT & 31.24 & 15.62 & 31.24 \\
\hline Streptomycin & 0.06 & 0.24 & 0.12 & 0.12 & NT & NT & NT \\
\hline
\end{tabular}

NT $=$ not tested

\section{Molecular docking study}

The results of the molecular docking study expressed as variation of Gibbs free energy $(\Delta \mathrm{G})$ and the consequent predicted inhibition constants are presented in Table III. Also, a clustering analysis was performed, taking into account the top binding conformation of each compound into the catalytic site of lanosterol $14 \alpha$-demethylase.

Overall, analysing the results obtained for compounds 5a-o, an obvious difference between then can be observed. Thiazolyl-salicylamide derivatives 5h-o, possessing an aromatic substituent on the etheric moiety, had a greater affinity for the enzyme, compared to 5a-g having a non-aromatic substituent. Between the molecules bearing an aromatic substituent, the best binding to target lanosterol $14 \alpha$-demethylase was predicted for $5 \mathbf{k}$ and $\mathbf{5 n}$ with $\Delta \mathrm{G}$ values of -10.99 and $-10.95 \mathrm{kcal} / \mathrm{mol}$, respectively.

Thus, these two compounds are predicted to have the lowest inhibition constants from the present series: $-8.79 \mathrm{kcal} / \mathrm{mol}$ and $-9.41 \mathrm{kcal} / \mathrm{mol}$, respectively. From the aromatic derivatives, the most homogenous binding was found for compound $\mathbf{5 n}$, with the highest number of conformations in the top binding cluster of the top binding conformation. This idea can be confirmed by the low number (9 conformations) of un-clustered residual conformations. The predicted binding conformation of compound $\mathbf{5 n}$ into the catalytic site of fungal lanosterol 14 $\alpha$-demethylase is depicted in Figure 2. Two important amino acid residues from the polar area of access channel to the active site are predicted to interact with the $\mathbf{5 n}$ ligand. Tyr132 is predicted to create a hydrogen bond with the ligand through the oxygen atom from the ketone, while Tyr118 is predicted to interact with the salicylamide fragment of the ligand. Those polar contacts are considered to be important for a good interaction with the macromolecule. The lipophilic side of the thiazole-salicylamide moiety is oriented into a lipophilic pocket from the access channel, created by the Leu376, Val509, Met508, Ile304, Pro230 and Phe233 sidechains.

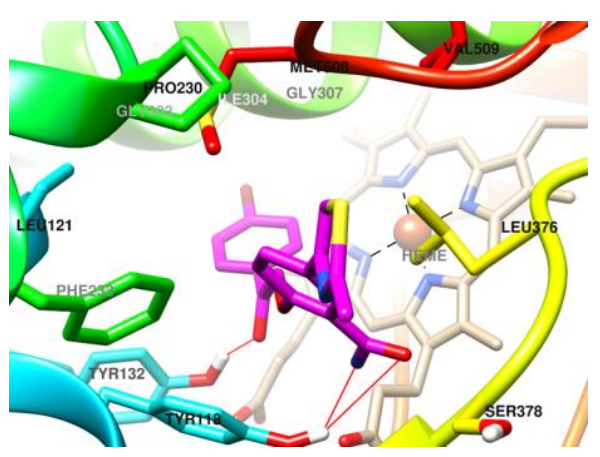

Figure 2.

Compound $\mathbf{5 n}$ docked into the catalytic site of fungal lanosterol $14 \alpha$-demethylase. Carbon atoms of the ligand in depicted in magenta, while the hydrogen bonds with red lines. Unnecessary amino acid residues were removed to ensure a better view.

The $p$-bromoacetophenone fragment of the $\mathbf{5 n}$ ligand is oriented into the depth of the catalytic site. The bromine atom fits well into a large lipophilic subpocket found between the heme side and two alpha helices (Asn136-Ala149 sequence, respectively Asp294Gly324 sequence). The oxymethylene bridge acts like a hinge, giving the molecule flexibility to ensure a better interaction with the biological target.

Lipophilicity evaluation

Lipophilicity results evaluations of compounds 5a-o, expressed as $\log \mathrm{P}$, are presented in Table III. The most lipophilic compounds from our series were $\mathbf{5 e}, \mathbf{5 n}, \mathbf{5 f}$ and 5k with $\log P$ values ranging between $3.05-2.79$. 
Results of the lipophilicity and the molecular docking studies for compounds 5a-o

\begin{tabular}{|c|c|c|c|c|c|c|}
\hline \multirow{3}{*}{ Compound } & \multirow{3}{*}{$\log P$} & \multicolumn{3}{|c|}{ The cluster with the top binding conformation } & \multirow{3}{*}{$\begin{array}{c}\text { Multi } \\
\text { membered } \\
\text { clusters }\end{array}$} & \multirow{3}{*}{$\begin{array}{c}\text { Residual } \\
\text { conformations }\end{array}$} \\
\hline & & \multicolumn{2}{|c|}{ Best binding conformation } & \multirow{2}{*}{ NoC } & & \\
\hline & & $\Delta \mathrm{G}(\mathrm{kcal} / \mathrm{mol})$ & $\mathbf{K i}(\mathbf{n M})$ & & & \\
\hline 5a & 2.71 & -8.19 & 992.31 & 67 & 18 & 16 \\
\hline $\mathbf{5 b}$ & 2.04 & -8.15 & 1061.61 & 22 & 21 & 10 \\
\hline 5c & 2.76 & -7.73 & 2156.90 & 7 & 14 & 6 \\
\hline 5d & 1.08 & -7.98 & 1414.42 & 22 & 13 & 11 \\
\hline 5e & 3.05 & -9.05 & 232.41 & 86 & 20 & 8 \\
\hline $5 \mathbf{f}$ & 2.88 & -8.21 & 959.37 & 73 & 15 & 13 \\
\hline $5 g$ & 1.38 & -8.75 & 385.62 & 17 & 19 & 10 \\
\hline $5 \mathrm{~h}$ & 1.84 & -10.26 & 30.15 & 18 & 30 & 22 \\
\hline $5 i$ & 2.52 & -10.67 & 15.09 & 25 & 23 & 11 \\
\hline $5 \mathrm{j}$ & 2.47 & -10.69 & 14.59 & 13 & 28 & 15 \\
\hline $5 \mathrm{k}$ & 2.79 & -10.99 & 8.79 & 15 & 23 & 12 \\
\hline 51 & 2.58 & -10.42 & 23.02 & 15 & 30 & 15 \\
\hline $5 \mathrm{~m}$ & 2.67 & -10.55 & 18.48 & 27 & 25 & 9 \\
\hline $5 n$ & 2.95 & -10.95 & 9.41 & 39 & 26 & 9 \\
\hline 50 & 2.00 & -10.58 & 17.57 & 23 & 28 & 17 \\
\hline
\end{tabular}

NoC represents "number of conformations"

\section{Conclusions}

In order to develop new antimicrobial agents, in the present study we report the synthesis of 15 novel 4thiazolyl-salicylamide derivatives. The compounds were physico-chemically and spectrally characterized. With the exception of one molecule, most derivatives exhibited low antibacterial and antifungal activities. The para-bromine substituted aromatic compound 5n exhibited good antifungal activity against $C$. albicans ATCC 10231, C. parapsilosis ATCC 22019 and $C$. zeylanoides ATCC 201082, comparable or equal to that of fluconazole. A molecular docking study revealed the structural features which influence the interaction with lanosterol $14 \alpha$-demethylase. The most active compound, 5n, was highly lipophilic and had good interactions with the target enzyme, knowing that these parameters are one of the most important for the antifungal effect.

\section{Acknowledgement}

The work reported in this paper was financially supported by 1526/39/18.01.2019 PCD grant of the "Iuliu Hațieganu" University of Medicine and Pharmacy, Cluj-Napoca, Romania and PN 19350201 grant, through the Core Program (Program Nucleu).

\section{Conflict of interest}

The authors declare no conflict of interest.

\section{References}

1. Bikobo DSN, Vodnar DC, Stana A, Tiperciuc B, Nastasă C, Douchet M, Oniga O, Synthesis of 2phenylamino-thiazole derivatives as antimicrobial agents. J Saudi Chem Soc., 2017; 21(7): 861-868.
2. Blejan IE, Diaconu CC, Arsene AL, Udeanu DI, Ghica M, Drăgănescu D, Burcea Dragomiroiu GTA, Rădulescu M, Maltezou HC, Tsatsakis AM, Papasavva M, Drakoulis N, Popa DE, Antibiotic resistance in community-acquired pneumonia. A Romanian perspective. Farmacia, 2020; 68(3): 512-520.

3. Breijyeh Z, Jubeh B, Karaman R, Resistance of Gram-Negative Bacteria to Current Antibacterial Agents and Approaches to Resolve It. Molecules, 2020; 25(6): 1340: 1-23.

4. Cebrián R, Rodríguez-Cabezas ME, Martín-Escolano R, Rubiño S, Garrido-Barros M, Montalbán-López M, Rosales MJ, Sánchez-Moreno M, Valdivia E, Martínez-Bueno M, Marín C, Gálvez J, Maqueda $\mathrm{M}$, Preclinical studies of toxicity and safety of the AS-48 bacteriocin. J Adv Res., 2019; 20: 129-139.

5. Chatterjee A, Modarai M, Naylor NR, Boyd SE, Atun R, Barlow J, Holmes AH, Johnson A, Robotham $\mathrm{JV}$, Quantifying drivers of antibiotic resistance in humans: a systematic review. Lancet Infect Dis., 2018; 18(12): e368-e378.

6. Daina A, Michielin O, Zoete V, SwissADME: a free web tool to evaluate pharmacokinetics, drug-likeness and medicinal chemistry friendliness of small molecules. Sci Rep., 2017; 7: 42717: 1-13.

7. Grossman S, Soukarieh F, Richardson W, Liu R, Mashabi A, Emsley J, Williams P, Cámara M, Stocks MJ, Novel quinazolinone inhibitors of the Pseudomonas aeruginosa quorum sensing transcriptional regulator PqsR. Eur J Med Chem., 2020; 208: 112778: 1-15.

8. Hannoun MH, Hagras M, Kotb A, El-Attar A-AMM, Abulkhair HS, Synthesis and antibacterial evaluation of a novel library of 2-(thiazol-5-yl)-1,3,4-oxadiazole derivatives against methicillin-resistant Staphylococcus aureus (MRSA). Bioorg Chem., 2020; 94: 103364: 1-10.

9. Manciuc C, Mihai IF, Filip-Ciubotaru F, Lacatusu GA, Resistance profile of multidrug-resistant urinary tract infections and their susceptibility to carbapenems. Farmacia, 2020; 68(4): 715-721. 
10. Marc G, Stana A, Pîrnău A, Vlase L, Vodnar DC, Duma M, Tiperciuc B, Oniga O, 3,5-Disubstituted Thiazolidine-2,4-Diones: Design, Microwave-Assisted Synthesis, Antifungal Activity, and ADMET Screening. SLAS Discov., 2018; 23(8): 807-814.

11. Mir F, Shafi S, Zaman MS, Kalia NP, Rajput VS, Mulakayala C, Mulakayala N, Khan IA, Alam MS, Sulfur rich 2-mercaptobenzothiazole and 1,2,3-triazole conjugates as novel antitubercular agents. Eur J Med Chem., 2014; 76: 274-283.

12. Molnar A, Antimicrobial Resistance Awareness and Games. Trends Microbiol., 2019; 27(1): 1-3.

13. Morris GM, Huey R, Lindstrom W, Sanner MF, Belew RK, Goodsell DS, Olson AJ, AutoDock4 and AutoDockTools4: Automated Docking with Selective Receptor Flexibility. J Comput Chem., 2009; 30(16): 2785-2791.

14. Osman H, Yusufzai SK, Khan MS, Abd Razik BM, Sulaiman O, Mohamad S, Gansau JA, Ezzat MO, Parumasivam T, Hassan MZ, New thiazolyl-coumarin hybrids: Design, synthesis, characterization, X-ray crystal structure, antibacterial and antiviral evaluation. J Mol Struct., 2018; 1166: 147-154.

15. Pettersen EF, Goddard TD, Huang CC, Couch GS, Greenblatt DM, Meng EC, Ferrin TE, UCSF Chimera-A visualization system for exploratory research and analysis. J Comput Chem., 2004; 25(13): 1605-1612.

16. Stoica CI, Ionuț I, Vlase L, Tiperciuc B, Marc G, Oniga S, Araniciu C, Oniga O, Lipophilicity evaluation of some thiazolyl-1,3,4-oxadiazole derivatives with antifungal activity. Biomed Chromatogr., 2018; 32(7): e4221: 1-7.

17. Tacconelli E, Sifakis F, Harbarth S, Schrijver R, van Mourik M, Voss A, Sharland M, Rajendran NB, Rodríguez-Baño J, Bielicki J, de Kraker M, Gandra S, Gastmeier P, Gilchrist K, Gikas A, Gladstone BP, Goossens H, Jafri H, Kahlmeter G, Leus F, Luxemburger C, Malhotra-Kumar S, Marasca G, McCarthy M, Navarro MD, Nuñez-Nuñez M, Oualim A, Price J, Robert J, Sommer H, von Cube M, Vuong C, Wiegand I, Witschi AT, Wolkewitz M, Surveillance for control of antimicrobial resistance. Lancet Infect Dis., 2018; 18(3): e99-e106.

18. Wang WL, Chai SC, Huang M, He HZ, Hurley TD, Ye QZ, Discovery of Inhibitors of Escherichia coli Methionine Aminopeptidase with the Fe(II)-Form Selectivity and Antibacterial Activity. J Med Chem., 2008; 51(19): 6110-6120. 